\title{
New approach to paricalcitol synthesis
}

\author{
LI LiQi, YUE LiRong, XUE JiJun*, XIE ZhiXiang \& LI Ying* \\ State Key Laboratory of Applied Organic Chemistry, Lanzhou University, Lanzhou 730000, China
}

Received April 1, 2011; accepted July 4, 2011; published online February 21, 2012

\begin{abstract}
Paricalcitol, an analog of vitamin D, is used as a drug for the prevention and treatment of secondary hyperparathyroidism. In this paper, a new strategy for the synthesis of paricalcitol is described. This approach includes three main improvements: one-pot regioselective ozonization cleavage of the side-chain and methylene at $\mathrm{C}-19$, free-radical reduction removal of the $\mathrm{OH}$ group formed at C-19, and side-chain assembly using a Wittig reaction. These are all new strategies for the synthesis of 19-nor-vitamin $\mathrm{D}_{2}$ compounds.
\end{abstract}

paricalcitol, synthesis, ozonization, Wittig reaction

Paricalcitol (1, Figure 1), a second-generation vitamin D receptor (VDR) activator, has been developed as a drug for the prevention and treatment of secondary hyperparathyroidism (SHPT) and of period III and IV chronic kidney diseases (CDK) [1]. The effect of paricalcitol on intestinal calcium resorption is less than that of calcitriol; this avoids undesirable hypocalcaemia [2]. Paricalcitol also retains significant immunomodulatory activity, comparable to that of calcitriol [3]. The immunomodulatory potency of paricalcitol makes it a drug of interest in the therapy of chronic immune-mediated inflammatory diseases.

Paricalcitol is of wide interest because of its known and potential applications. The original synthesis [4,5] used a convergent strategy. Three key parts were prepared respectively from vitamin $\mathrm{D}_{2}$, quinic acid, and methyl 2methyl-3-hydroxypropionate, and assembled to form paricalcitol in 19 steps. Another synthesis [6] started from ergosterol and used ozonization, with Julia coupling as the key steps. A modification of the introduction of the sidechain of paricalcitol was reported by $\mathrm{Ng}$ and co-workers [7], who used a Wittig-Horner reaction instead of Julia olefination. The most recent synthesis [8] still started from vitamin $\mathrm{D}_{2}$ and involved 17 steps. The assembly of side-chains and

\footnotetext{
*Corresponding authors (email: xuejj@1zu.edu.cn; liying@1zu.edu.cn)
}

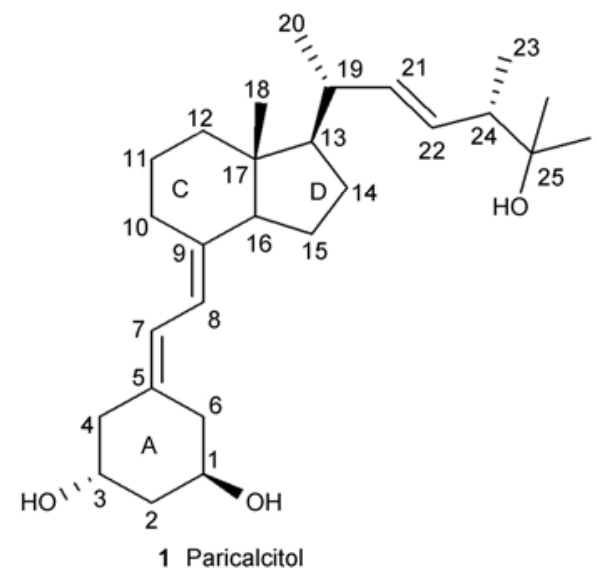

Figure 1 Structure of paricalcitol.

cleavage of the methylene group on ring $A$ of vitamin $D_{2}$ were achieved by ozonization/Julia olefination and dihydroxylation/oxidation with $\mathrm{NaIO}_{4}$, respectively.

Large-scale, efficient, convenient synthesis of paricalcitol is still a challenge. We therefore tried to find an efficient synthetic method. First, we tried to improve the main conversion steps, especially removal of the C-19 methylene group and assembly of the side-chain. It was found that the side-chain and C-19 methylene can be cleaved selectively in 
one-pot ozonization instead of by ozonization/dihydroxylation/oxidation cleavage of $\mathrm{NaIO}_{4}$; the formed $\mathrm{C}-19 \mathrm{OH}$ group was removed by free-radical reduction instead of reduction using $\mathrm{LiAlH}_{4}$, and the side-chain was assembled using a Wittig reaction instead of Julia coupling/olefination. These improvements made the synthesis more convenient and efficient.

The synthesis started from commercially available vitamin $\mathrm{D}_{2}$, which has a skeleton similar to that of paricalcitol. Because both the methylene group and the side-chain can be cleaved by ozonization, cleavage can be performed in one pot using ozone. Reaction of vitamin $\mathrm{D}_{2}$ with $p$-toluenesulfonyl chloride ( $\mathrm{TsCl}$ ) in pyridine gave tosylate $\mathbf{3}$ in $88 \%$ yield. Treatment of 3 with $\mathrm{K}_{2} \mathrm{CO}_{3}$ in methanol gave compound 4 in $67 \%$ yield [9], in which one double bond was protected and the methylene group on ring $\mathrm{A}$ and the double bond of the side-chain remained. Allylic oxidation of 4 to introduce 1- $\alpha-\mathrm{OH}$ proceeded by allylic oxidation with $\mathrm{SeO}_{2}$ [10]. It was found that $t$-butyl hydroperoxide (TBHP) is a better co-oxidant than $\mathrm{N}$-methylmorphine $N$-oxide (NMO). In dichloromethane $\left(\mathrm{CH}_{2} \mathrm{Cl}_{2}\right) /$ methanol $(\mathrm{MeOH})(3: 1, \mathrm{v} / \mathrm{v})$ as solvent and using $\mathrm{SeO}_{2} / \mathrm{TBHP}$ and $\mathrm{SeO}_{2} / \mathrm{NMO}$ as oxidants, 5 yielded in $58 \%$ and $40 \%$ yields from 4, respectively. Importantly, both of these two oxidations gave a single $1-\alpha-\mathrm{OH}$ product 5 after column chromatography (Figure 2).

The first important step in the synthesis is the one-pot ozonization of the methylene group and the side-chain. Compound 5 was treated with either $\mathrm{MeOCH}_{2} \mathrm{Cl}$ and diisopropylethylamine (DiPEA) in $\mathrm{CH}_{2} \mathrm{Cl}_{2}$ or acetic anhydride $\left(\mathrm{Ac}_{2} \mathrm{O}\right)$ and pyridine (Py) in $\mathrm{CH}_{2} \mathrm{Cl}_{2}$ or $t$-butyldimethylsilyl chloride (TBDMSCl) and imidazole in $N, N$-dimethylformide (DMF) to protect the $\mathrm{OH}$ group. The corresponding protected products $\mathbf{6 a}, \mathbf{6 b}$, and $\mathbf{6 c}$ were formed in $90 \%$, $86 \%$, and $80 \%$ yields, respectively. The ozonization of each of $\mathbf{6 a}, \mathbf{6 b}$, and $\mathbf{6 c}$ was carried out in $\mathrm{CH} 2 \mathrm{Cl} 2 / \mathrm{MeOH}(1: 1, \mathrm{v} / \mathrm{v})$ at $-65^{\circ} \mathrm{C}$. After the starting material had all reacted, $\mathrm{NaBH}_{4}$ was added to quench the reaction. Compounds $\mathbf{7} \mathbf{a}^{1)}, \mathbf{7 b}$, and 7c were obtained from the corresponding substrates in $62 \%$, $40 \%$, and $52 \%$ yields, respectively, as single isomers (Figure 3). Neither the configurations of $\mathbf{7 a - 7 c}$, nor those of the corresponding subsequent compounds 8-13, are known.

The second challenge in the synthesis is the removal of the $\mathrm{OH}$ group on $\mathrm{C}-19$ of compound 7a. First, 7a was reacted with $\mathrm{Ac}_{2} \mathrm{O}$ and pyridine in $\mathrm{CH}_{2} \mathrm{Cl}_{2}$ to protect the primary $\mathrm{OH}$. In accordance with the literature [11], 8a was

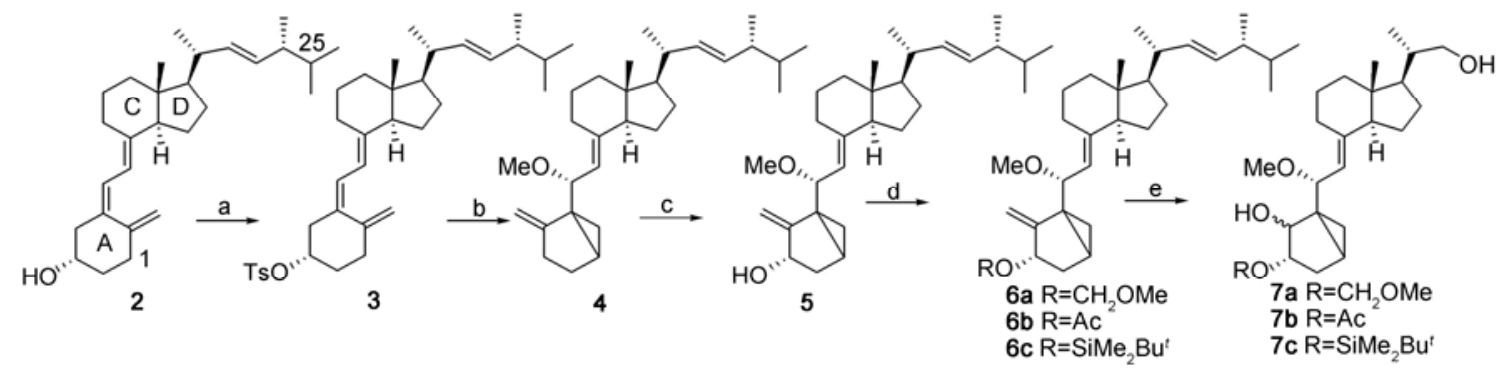

Figure 2 Synthesis of intermediates 7a-7c. Reagents and conditions: a) TsCl, pyridine, rt, 10 h, $88 \%$; b) $\mathrm{K}_{2} \mathrm{CO}_{3}, \mathrm{MeOH}$, reflux, 5 h, $67 \%$; c) SeO , TBHP, $\mathrm{CH}_{2} \mathrm{Cl}_{2}, \mathrm{MeOH}$, reflux, 58\%; d) $\mathrm{MeOCH}_{2} \mathrm{Cl}$, DiPEA, $\mathrm{CH}_{2} \mathrm{Cl}_{2}$, rt, $7 \mathrm{~h}, 90 \%$ yield for $\mathbf{6 a}$; $\mathrm{Ac}_{2} \mathrm{O}$, pyridine, $\mathrm{CH}_{2} \mathrm{Cl}_{2}, \mathrm{rt}, 6 \mathrm{~h}, 86 \%$ yield for $\mathbf{6 b}$; TBDMSCl, imidazole, DMF, $80 \%$ yield for $\mathbf{6 c}$; e) i. $\mathrm{O}_{3}, \mathrm{CH}_{2} \mathrm{Cl}_{2}, \mathrm{MeOH}$; ii. $\mathrm{NaBH}_{4} ;-78^{\circ} \mathrm{C}, 62 \%$ for $7 \mathbf{a}, 40 \%$ for $7 \mathbf{b}$, and $52 \%$ for $7 \mathbf{c}$.

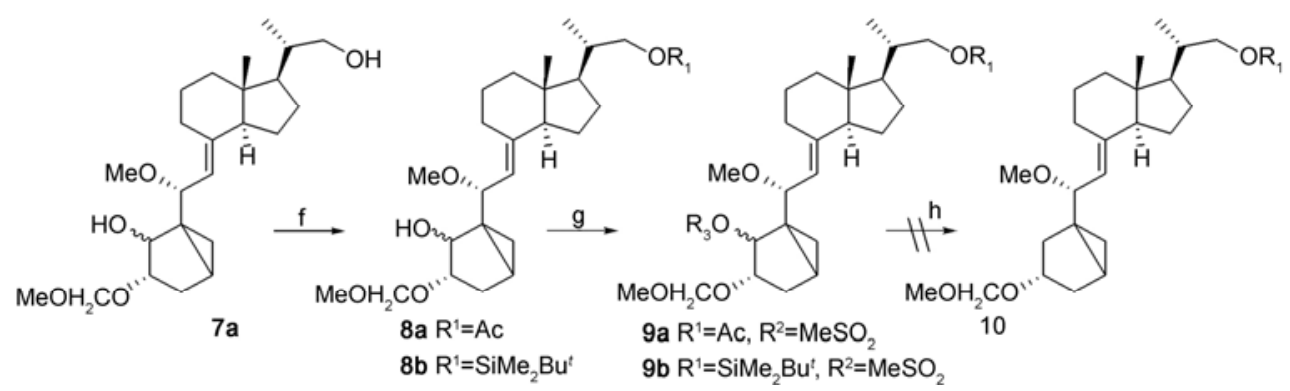

Figure 3 Removal of $\mathrm{OH}$ group on ring A of 8a. Reagents and conditions: f) $\mathrm{Ac}_{2} \mathrm{O}$, pyridine, $\mathrm{CH}_{2} \mathrm{Cl}_{2}, \mathrm{rt}, 3 \mathrm{~h}, 85 \%$ for $\mathbf{8 a}$; TBDMSCl, imidazole, DMF, rt, 1 h, 78\% for 8b; g) 9a: $\mathrm{MsCl}, \mathrm{Et}_{3} \mathrm{~N}, 0^{\circ} \mathrm{C}, 1 \mathrm{~h}$; 9b: i. NaH, THF, $\mathrm{CS}_{2}$, reflux, 3 h; ii. MeI, reflux, 3 h; 67\% for 9b; 9c: 1,1'-diimidazole carbonyl, DMAP, $\mathrm{CH}_{2} \mathrm{Cl}_{2}, 1$ h, $84 \%$ for 9c; 9d: $\left.\mathrm{MsCl}, \mathrm{Et}_{3} \mathrm{~N}, \mathrm{CH}_{2} \mathrm{Cl}_{2} ; \mathrm{h}\right) \mathrm{LiAlH}_{4}, \mathrm{THF}$, rt, for 9a and 9d; $\mathrm{Bu}_{3} \mathrm{SnH}$, AIBN, toluene, reflux, for 9b and 9c.

1) The spectrum data of 7a: ${ }^{1} \mathrm{H}$ NMR $(300 \mathrm{MHz}, \delta) 0.57(3 \mathrm{H}, \mathrm{s}), 0.65(1 \mathrm{H}, \mathrm{m}), 0.80-0.87(2 \mathrm{H}, \mathrm{m}), 1.04(3 \mathrm{H}, \mathrm{d}, J=6.6 \mathrm{~Hz}), 1.27-1.35(3 \mathrm{H}, \mathrm{m})$, $1.47-1.55(3 \mathrm{H}, \mathrm{m}), 1.61-1.67(3 \mathrm{H}, \mathrm{m}), 1.84-2.01(6 \mathrm{H}, \mathrm{m}), 2.81(1 \mathrm{H}, \mathrm{d}, J=10.5 \mathrm{~Hz}), 3.05(1 \mathrm{H}, \mathrm{s}), 3.16(3 \mathrm{H}, \mathrm{s}), 3.34(3 \mathrm{H}, \mathrm{s}), 3.50(1 \mathrm{H}, \mathrm{m}), 3.62(1 \mathrm{H}, \mathrm{dd}, J=$ $2.1,10.5 \mathrm{~Hz}), 3.65(1 \mathrm{H}, \mathrm{dd}, J=2.4,6.9 \mathrm{~Hz}), 3.98(1 \mathrm{H}, \mathrm{d}, J=4.2 \mathrm{~Hz}), 4.58(1 \mathrm{H}, \mathrm{d}, J=9.6 \mathrm{~Hz}), 4.59(2 \mathrm{H}, \mathrm{m}), 4.75(1 \mathrm{H}, \mathrm{d}, J=9.6 \mathrm{~Hz}) .{ }^{13} \mathrm{C} \mathrm{NMR}(75 \mathrm{MHz}, \delta)$ 9.6, 11.8, 16.8, 18.2, 22.2, 23.6, 27.1, 29.3, 31.0, 34.3, 39.0, 40.3, 45.5, 52.8, 55.5, 55.6, 67.7, 72.6, 73.9, 77.2, 96.2, 119.3, 144.0. ESI-HRMS $(m / z)\left[\mathrm{M}+\mathrm{Na}{ }^{+}\right]$ 431.2763 (Calc. 431.2768 ). 
mesylated with methanesulfonyl chloride $(\mathrm{MsCl})$ and triethylamine $\left(\mathrm{Et}_{3} \mathrm{~N}\right)$ in $\mathrm{CH}_{2} \mathrm{Cl}_{2}$ to form compound $\mathbf{9 a}$ and the crude 9a was subsequently reduced using $\mathrm{LiAlH}_{4}$ in THF before purification. Unfortunately, these two reaction steps were messy, and $\mathbf{1 0}$ was not found. Detailed investigations found that very little 9a was formed in the mesylation. To avoid the effect of the actyl group in the reduction, $\mathbf{8 b}$ was prepared from $\mathbf{7 a}$ in $78 \%$ yield. The mesylation of $\mathbf{8 b}$, followed by reduction of $\mathbf{9 b}$, was also messy and failed to give 10. Investigation of the side-products proved that the three-membered ring is unstable under these reductive conditions. So, another approach was proposed, as shown in Figure 4.

Compound 8a was treated with acetic acid $(\mathrm{AcOH})$ in dimethyl sulfoxide (DMSO) and $\mathbf{1 1}$ was formed in $72 \%$ yield as a single isomer after purification by column chromatography [12-15]. The double-bond configuration of compound $\mathbf{1 1}$ is not known for certain and those of the subsequent products 12-19 are also unclear. The protection of 11 with $\mathrm{MeOCH}_{2} \mathrm{Cl} / \mathrm{DiPEA}$ gave an $\mathrm{OH}$-free product in which the two $\mathrm{OH}$ groups of $\mathbf{1 1}$ were protected. So, a bulky group TBDMS was used as the protection group and $\mathbf{1 2}$ was obtained in $75 \%$ yield. Procedures similar to the protection of $8 \mathbf{a}$ converted 12 to 13a-13c. Compounds 13a, 13b, and 13c were prepared in $38 \%, 57 \%$, and $78 \%$ yields, respec- tively. Compound 13a was reduced with $\mathrm{LiAlH}_{4}$ in THF and only a trace of $\mathbf{1 4}$ was found. Free-radical reduction of 13b with tributyltin hydride $(\mathrm{Bu} 3 \mathrm{SnH})$ and azodiisobutrnitrile (AIBN) in toluene under reflux [16] gave the desired dehydroxylated product $\mathbf{1 4}$ in $48 \%$ yield. However, the reduction of $\mathbf{1 3 c}$ only gave $\mathbf{1 2}$ along with some useless products.

At this point, the skeleton of the target compound had been constructed. The last important step is to introduce a new side-chain. Julia olefination [8] and the Wittig reaction [7] are general methods for this kind of conversion. As in the scheme shown in Figure 4, 14 was deprotected with $\mathrm{K}_{2} \mathrm{CO}_{3}$ in $\mathrm{MeOH}$, followed by Swern oxidation; aldehyde $16^{2)}$ was formed in $62 \%$ yield from 14 . The side-chain 17 was prepared from ester 20. Grignard reaction of $\mathbf{2 0}$ with 3.0 equivalents of $\mathrm{MeMgBr}$ in $\mathrm{Et}_{2} \mathrm{O}$ gave 21 in quantitative yield. Compound 21 reacted with $\mathrm{TsCl}$ and pyridine in $\mathrm{CH}_{2} \mathrm{Cl}_{2}$ to form tosylate 22 in $85 \%$ yield [17]. Nucleophilic substitution of $\mathbf{2 2}$ with $\mathrm{NaI}$ in acetone gave $\mathbf{2 3}$ in $77 \%$ yield. After protection, $\mathbf{2 4}^{3)}$ was heated with $\mathrm{PPh}_{3}$, without a solvent, and 17 was formed. Trituration of the reaction mixture with $\mathrm{Et}_{2} \mathrm{O}$ and $\mathrm{CH}_{2} \mathrm{Cl}_{2}$ by turns gave the purified side-chain 17. The yields of $\mathbf{1 7}$ from $\mathbf{2 3}$ are 30\%-60\%, depending on the protecting group. Sulfone $\mathbf{2 5}$ was prepared according to the literature method [18].

As the scheme shown in Figure 4, compound 17a was

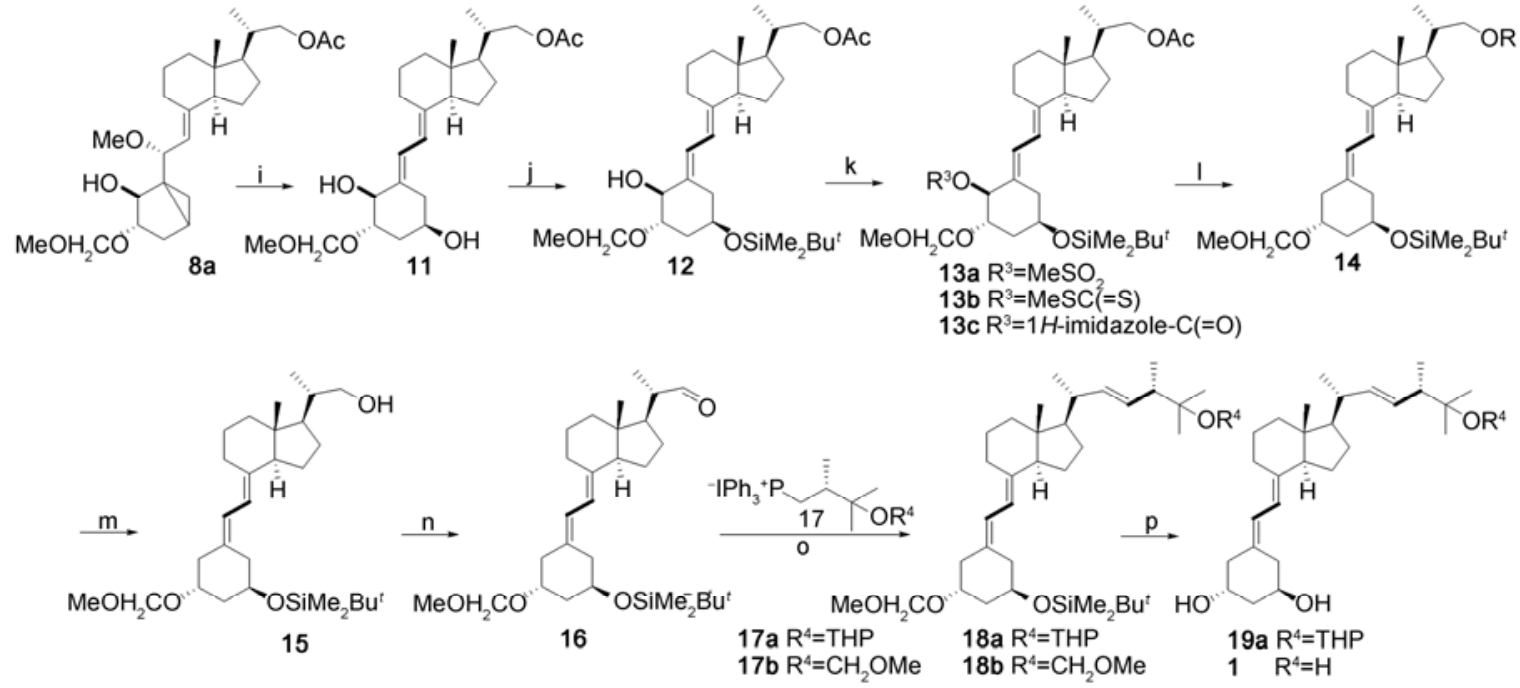

Figure 4 Alternative method for removing the $\mathrm{OH}$ group of 8a. Reagents and conditions: i) $\mathrm{AcOH}, \mathrm{DMSO}, 50^{\circ} \mathrm{C}, 1 \mathrm{~h}, 72 \%$; j) TBDMSCl, imidazole, DMF, rt, 2 h, 75\%; k) 13a: $\mathrm{MsCl}, \mathrm{Et}_{3} \mathrm{~N}, \mathrm{CH}_{2} \mathrm{Cl}_{2}, 0^{\circ} \mathrm{C}$; 13b: i. $\mathrm{NaH}$, THF, $\mathrm{CS}_{2}$, reflux, $3 \mathrm{~h}$; ii. MeI, reflux, $3 \mathrm{~h}, 57 \%$ for 13b; 13c: 1,1'-diimidazole carbonyl, DMAP, $\mathrm{CH}_{2} \mathrm{Cl}_{2}$, rt, $78 \%$ for 13c; l) $\mathrm{LiAlH}_{4}$, THF, rt, for 13a; $\mathrm{Bu}_{3} \mathrm{SnH}$, AIBN, toluene, reflux, $1 \mathrm{~h}, 48 \%$ for 13b; m) $\mathrm{K}_{2} \mathrm{CO}_{3}, \mathrm{MeOH}$, reflux, $\left.3 \mathrm{~h} ; \mathrm{n}\right)(\mathrm{COCl})_{2}$, DMSO, $\mathrm{CH}_{2} \mathrm{Cl}_{2}, \mathrm{Et}_{3} \mathrm{~N},-78^{\circ} \mathrm{C}, 62 \%$ for two steps; o) i. $n$-BuLi, THF, $-78^{\circ} \mathrm{C}-\mathrm{rt}, 1 \mathrm{~h}$; ii. $17, \mathrm{THF}, 10 \mathrm{~h}, 72 \%$ for $18 \mathrm{a}, 63 \%$ for $18 \mathbf{b}$; p) $19 \mathrm{a}$ : PPTs, $95 \% \mathrm{EtOH}$, reflux, 2 h, $70 \% ; 1: \mathrm{ZrCl}_{4}, i-\mathrm{PrOH}$, reflux, 5 h, $65 \%$.

2) The spectrum data of 16: ${ }^{1} \mathrm{H}$ NMR $(300 \mathrm{MHz}, \delta) 0.05(6 \mathrm{H}, \mathrm{s}), 0.57(3 \mathrm{H}, \mathrm{s}), 0.86(9 \mathrm{H}, \mathrm{s}), 1.12(3 \mathrm{H}, \mathrm{d}, J=6.9 \mathrm{~Hz}), 1.40(1 \mathrm{H}, \mathrm{m}), 1.50-1.75(8 \mathrm{H}, \mathrm{m})$, 1.87-2.02 (4H, m), 2.06-2.16 (1H, m), 2.29-2.43 (3H, m), $2.54(1 \mathrm{H}, \mathrm{dd}, J=6.0,14.1 \mathrm{~Hz}), 2.82(1 \mathrm{H}, \mathrm{dd}, J=3.9,10.5 \mathrm{~Hz}), 3.34(3 \mathrm{H}, \mathrm{s}), 3.95-4.03(2 \mathrm{H}, \mathrm{m})$, $4.64(2 \mathrm{H}, \mathrm{dd}, J=6.6,9.3 \mathrm{~Hz}), 5.84(1 \mathrm{H}, \mathrm{d}, J=11.1 \mathrm{~Hz}), 6.20(1 \mathrm{H}, \mathrm{d}, J=11.7 \mathrm{~Hz}), 9.57(1 \mathrm{H}, \mathrm{s}) .{ }^{13} \mathrm{C}$ NMR $(75 \mathrm{MHz}, \delta) 4.7,12.4,13.5,18.1,22.6,23.1,25.8$, $26.4,28.6,33.5,40.1,40.7,45.8,46.0,49.7,51.3,55.2,55.4,67.8,72.7,94.8,116.2,121.8,133.5,140.5,205.0$. ESI-HRMS $(\mathrm{m} / \mathrm{z})\left[\mathrm{M}+\mathrm{K}^{+}\right] 529.3118$, $\left[\mathrm{M}+\mathrm{Na}^{+}\right] 513.3370($ Calc. 513.3371$),\left[\mathrm{M}+\mathrm{NH}_{4}{ }^{+}\right] 508.3826$.

3) The spectrum data of $\mathbf{2 4 c}:{ }^{1} \mathrm{H}$ NMR $(300 \mathrm{MHz}, \delta) 1.08(3 \mathrm{H}, \mathrm{d}, J=5.7 \mathrm{~Hz}), 1.12(3 \mathrm{H}, \mathrm{s}), 1.23(3 \mathrm{H}, \mathrm{s}), 1.97(1 \mathrm{H}, \mathrm{m}), 2.85(1 \mathrm{H}, \mathrm{dd}, J=9.3,11.1 \mathrm{~Hz})$, $3.35(3 \mathrm{H}, \mathrm{s}), 3.68(1 \mathrm{H}, \mathrm{dd}, J=1.8,9.3 \mathrm{~Hz}), 4.67(2 \mathrm{H}, \mathrm{m})$. 


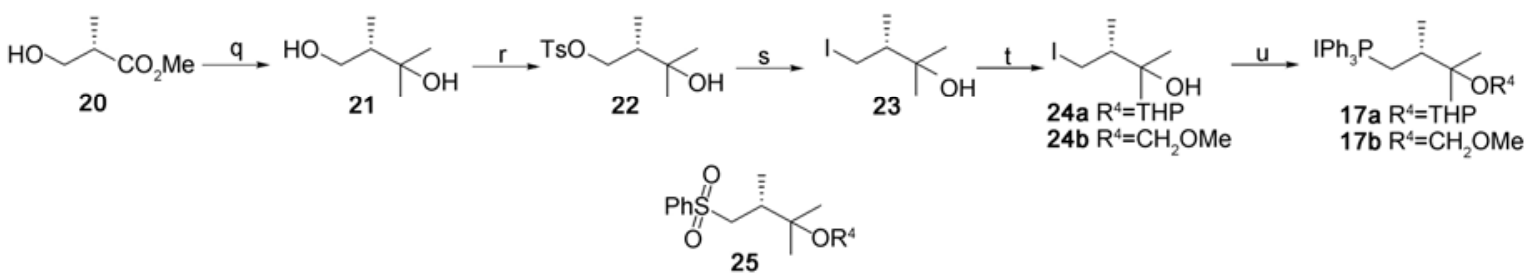

Figure 5 Side-chain preparation. Reagents and conditions: q) MeMgBr, $\mathrm{Et}_{2} \mathrm{O}$, reflux, $3 \mathrm{~h}, 98 \%$; r) TsCl, pyridine, rt, 2 h, $85 \%$; s) $\mathrm{NaI}$, acetone, reflux, $10 \mathrm{~h}$, $77 \%$; t) 3, 4-DHP, cat. $p$-TsOH, $\mathrm{CH}_{2} \mathrm{Cl}_{2}$, rt, overnight, $83 \%$ for $\mathbf{2 4 a} ; \mathrm{MeOCH}_{2} \mathrm{Cl}, \mathrm{DiPEA}, \mathrm{CH}_{2} \mathrm{Cl}_{2}, \mathrm{rt}, 4 \mathrm{~h}, 88 \%$ for $\mathbf{2 4 b}$; u) $\mathrm{PPh}_{3}, 100{ }^{\circ} \mathrm{C}, 40 \mathrm{~h}, 60 \%$ for $\mathbf{1 7 a}$ and $66 \%$ for $\mathbf{1 7 b}$.

deprotonated with $n$ - $\mathrm{BuLi}$ at $-78^{\circ} \mathrm{C}$, and then the generated anion reacted with $\mathbf{1 6}$ in situ to form 18a in $72 \%$ yield in a 4:3 trans/cis ratio. The mixture cannot be separated by flash silica-gel column chromatography and the trans/cis ratio was determined by ${ }^{1} \mathrm{H}$ NMR. Other strong bases such as $\mathrm{MeLi}, \mathrm{PhLi}$, and potassium $t$-butoxide $(t$-BuOK) did work in this reaction, but did not improve the conversion rate or the selectivity. Similar results were also observed in the reaction of $\mathbf{1 7 b}$ with $\mathbf{1 6}$. The yield of $\mathbf{1 7 b}$ was $63 \%$. Unexpectedly, a similar reaction of $\mathbf{1 6}$ and $\mathbf{2 5}$, using a literature procedure [18], did not give any useful products.

Removal of the protecting groups on $\mathbf{1 8 a}$ and $\mathbf{1 8 b}$ is a challenge. Many methods, including protonic conditions and Lewis acid conditions, have been reported to remove $\mathrm{SiMe}_{2} \mathrm{Bu}^{t}$, THP, THF, and $\mathrm{CH}_{2} \mathrm{OMe}$. However, the THP of $18 \mathrm{a}$ and THF of $\mathbf{1 8 b}$ cannot be removed. Reactions with $p$-toluenesulfonic acid ( $p$ - $\mathrm{TsOH})$ in aqueous ethanol, 3 $\mathrm{mol} / \mathrm{L} \mathrm{HCl}$ in methanol, $\mathrm{MgBr}_{2}$ in THF, Dowex resins, $\mathrm{ZrCl}_{4}$ in $i$-propanol $(i$-PrOH), pyridium $p$-toluenesulfonate (PPTs)in ethanol (EtOH), Py·HF in THF, tetrabutylammonium fluoride (TBAF) in tetrahydrofuran (THF), etc. simply converted 18a to 19a. Strong Lewis acids such as $\mathrm{AlCl}_{3}$ and $\mathrm{BF}_{3} \cdot \mathrm{Et}_{2} \mathrm{O}$ did not remove THP and THF, and also decomposed most of the substrate. After screening a great many reagents, solvents, and reaction temperatures, $\mathbf{1}^{4)}$ was obtained in $65 \%$ yield by refluxing $18 \mathrm{~b}$ with $\mathrm{ZrCl}_{4}$ in $i$-PrOH.

In conclusion, a new synthesis of paricalcitol was achieved in 14 steps. This approach had major improvements on previous syntheses. First, the C-19 methylene group was removed by ozonization and free-radical reduction; this is more efficient strategy than that trough dihydroxylation, cleavage, protection, and reduction. Second, the side-chain was assembled by ozonization and a Wittig reaction rather than by ozonization, Julia coupling, and olefination; this is a shorter conversion and is also heavy-metalfree conversion. More importantly, the ozonization of the side-chain and methylene group was a one-pot reaction; this is the first use of selective ozonization in the synthesis of paricalcitol. This synthesis is not only important for the research on and development of paricalcitol, but is also of value in research on vitamin D analogs. This is the shortest synthesis of paricalcitol to date, and will be applicable after further modifications.

This work was supported by the National Natural Science Foundation of China (20802028 and 21072084).

1 Martin K J, Gonzalez E A, Gellens M, et al. J Am Soc Nephrol, 1998, 9: $1427-1432$

2 Deluca H F, Schnoes H K, Perlman K L, et al. European Patent Application, EP0387077, 1990

3 Truitt G A, Benjamin W R, Devens B H, et al. United States Patent, US4749710, 1985

4 Deluca H F, Schnoes H K, Perlman K L, et al. United States Patent, US5281731, 1994

5 Deluca H F, Schnoes H K, Perlman K L. United States Patent, US5086191, 1992

6 Toyoda A, Nagai H, Konuki K. International Application Published Under Property Cooperation Treaty (PCT), 2008, WO2008053961

$7 \quad \mathrm{Ng}$ C S, Wei C P. United States Patent, US007491712, 2009

8 Bader T, Stutz A, Bichsel H U, et al. International Application Published Under Property Cooperation Treaty (PCT), WO2010009879

9 Okamura W H, Zhu G D, Hill D K, et al. J Org Chem, 2002, 67: $1637-1650$

10 Knutson J C, Mazess R B, Bishop C W. United States Patent, US6903083, 2005

11 Deluca H F, Schnoes H K, Perlman C L, et al. United States Patent, US5587497, 1996

12 Wang Q L, Huang Q G, Chen B, et al. Angew Chem Int Ed, 2006, 45: 3651-3653

13 Barton D H R, McCombie S W. J Chem Soc Perkin Tran, 1975, 2: 1574-1585

14 Barton D H R, Lobberding D C A, Zard S Z. Tetrahedron, 1986, 42: 2329

15 Crich D, Quintero L. Chem Rev, 1989, 89: 1413-1432

16 Sheves M, Mazur Y. J Am Chem Soc, 1975, 97: 6249-6250

17 Beszant S, Giannini E, Zanoni G, et al. Eur J Org Chem, 2003, 20: 3958-3968

18 Deluca H F, Schnoes H K, Perlman K L. United States Patent, US5260290, 1993

Open Access This article is distributed under the terms of the Creative Commons Attribution License which permits any use, distribution, and reproduction in any medium, provided the original author(s) and source are credited.

4) The spectrum data of paricalcitol (1): ${ }^{1} \mathrm{H}$ NMR $(300 \mathrm{MHz}, \delta) 0.58(3 \mathrm{H}, \mathrm{s}), 0.99(6 \mathrm{H}, \mathrm{m}), 1.18(3 \mathrm{H}, \mathrm{s}), 1.26(3 \mathrm{H}, \mathrm{s}), 1.38(1 \mathrm{H}, \mathrm{m}), 1.46(3 \mathrm{H}, \mathrm{m})$, $1.67-1.83(8 \mathrm{H}, \mathrm{m}), 1.92-2.00(3 \mathrm{H}, \mathrm{m}), 2.19-2.27(2 \mathrm{H}, \mathrm{m}), 2.48(1 \mathrm{H}, \mathrm{m}), 2.71(1 \mathrm{H}, \mathrm{m}), 2,79(1 \mathrm{H}, \mathrm{m}), 4.05(1 \mathrm{H}, \mathrm{m}), 4.11(1 \mathrm{H}, \mathrm{m}), 5.18(1 \mathrm{H}, \mathrm{dd}, J=9.9,11.1$ $\mathrm{Hz}), 5.35(1 \mathrm{H}, \mathrm{dd}, J=9.6,11.1 \mathrm{~Hz}), 5.84(1 \mathrm{H}, \mathrm{d}, J=11.1 \mathrm{~Hz}), 6.30(1 \mathrm{H}, \mathrm{d}, J=11.1 \mathrm{~Hz}) .{ }^{13} \mathrm{C} \mathrm{NMR}(75 \mathrm{MHz}, \delta) 12.4,16.4,21.7,21.3,22.2,25.4,26.6,26.9$, 27.7, 28.9, 34.0, 37.0, 40.3, 42.1, 42.7, 44.6, 45.6, 56.2, 60.4, 67.1, 72.7, 115.3, 123.2, 128.2, 131.3, 138.3, 142.7. ESI-HRMS (m/z) $\left[\mathrm{M}+\mathrm{NH}{ }_{4}^{+}\right]$434.3623 (Calc. 434.3629). 